\title{
The Combination of Spirulina Extract and Sambiloto Effect Histopathologically on Medial Colon from Plasmodium berghei Anka Infected Mice
}

\author{
Kusmardi Kusmardi ${ }^{1}$, Rahyussalim², Rizky Priambodo Wisnubaroto ${ }^{2, *}$, Dilla Firzani ${ }^{3}$
}

\section{Kusmardi Kusmardi ${ }^{1}$, Rahyussalim², Rizky Priambodo Wisnubaroto ${ }^{2, *}$, Dilla Firzani ${ }^{3}$}

\section{'Department of Pathological Anatomy, Faculty of Medicine Indonesia, Universitas Indonesia, INDONESIA. ${ }^{2}$ Department of Orthopaedic and Traumatology, Faculty of Medicine, Universitas Indonesia, INDONESIA. ${ }^{3}$ Undergraduate student Faculty of Medicine, Universitas Indonesia, INDONESIA. \\ Correspondence}

\section{Dr. Rizky Priambodo Wisnubaroto}

No.71, Salemba, Jalan Pangeran Diponegoro, Kenari, RW.5, Kenari, Senen, Kota Jakarta Pusat,

Daerah Khusus Ibukota Jakarta 10430, INDONESIA.

E-mail: rizkypw.ortho@gmail.com

History

- Submission Date: 06-10-2018;

- Review completed: 27-11-2018;

- Accepted Date: 06-02-2019

DOI : 10.5530/pj.2019.11.90

Article Available online

http://www.phcogj.com/v11/i3

Copyright

(c) 2019 Pharmacognosy Journal. This is an open-access article distributed under the terms of the Creative Commons Attribution 4.0 International license.

\begin{abstract}
Introduction: Malaria is one of the biggest burden in medical section in Indonesia, as the prevalence is still high and half of the provinces in Indonesia considered as endemic area. ${ }^{1-4}$ Moreover, the drug resistant case number has grown larger within years. ${ }^{3-7}$ Indonesian people are very close with traditional drug regiment that derived from plants, for example Sambiloto

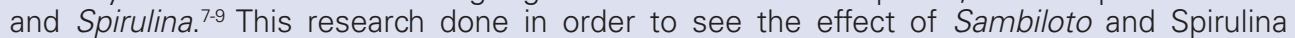
combination from histopathologic aspect in medial colon of $P$. berghei infected mice. Method: The data taken from experimental study using male Swiss Webster mice that has been infected with Plasmodium berghei Anka. The four groups of mice were given different treatment. The first group treated with Sambiloto only, the second one with Sambiloto and Spirulina extract, the third group with Sambiloto and Spirulina powder and the last one the control group with administration of DHP. Results: The result shows that the group with extract and powder spirulina show a significant result in the inflammatory focus and angiogenesis. However, this research does not necessarily prove the correlation between Sambiloto-Spirulina and their effect on the goblet cell and dysplasia grade on the infected mice, as the result for both category is insignificant. Conclusion: The study showed that spirulina has positive effect on inflamatory focus and angiogenesis, but the goblet cells count and dysplasia grade result is not noteworthy, as it requires prolonged inflammation process in order to achieve the optimal result.
\end{abstract}

Key words: Sambiloto, Spirulina, Malaria, Medial colon, Plasmodium berghei Anka.

\section{INTRODUCTION}

Malaria is one of the biggest medical burden in Indonesia, as the prevalence is still high and half of the provinces in Indonesia are considered as endemic area. ${ }^{1-4}$ Moreover, the drug resistant case number has grown larger within years. ${ }^{3-7}$ Indonesian people are very close with traditional drug regiment that derived from plants, for example Sambiloto and Spirulina. ${ }^{7-9}$ This research was performed in order to see the effect of Sambiloto and Spirulina combination toward histopathologic aspect in medial colon of $P$. berghei infected mice.

\section{MATERIALS AND METHODS}

This research used true experimental design, as the project conducted using experimental method and aim to see the cause-effect relationship and comparison between the control and the treated group. It took place in the Pathological Anatomy Laboratorium in Fakultas Kedokteran Universitas Indonesia, Salemba Campus. The research was carried out from February 2016 until May 2016.
The research used experimental animal, which is male Swiss Webster Mice. The subject animals weighed 24-28 grams and were around 8-10 weeks old. In this research, there were four groups of mice. All of the treatment were given orally. The first group of infected mice treated with $200 \mathrm{mg} / \mathrm{kg}$ BW of Sambiloto, the second group were given $26 \mathrm{mg} / \mathrm{kg}$ BW of Sambiloto and Spirulina extract combination, the third group were given $130 \mathrm{mg} / \mathrm{kg}$ BW of Sambiloto and Spirulina powder combination and the last group was control group which were given DHP.

Then, the colon tissue of the mice was harvested for histopathological examination. The colon cells were observed and examined using microscope with $10 \mathrm{x}$ 40 magnifications. The variable to which were measured included number of goblet cells, inflammatory foci, angiogenesis and dysplasia.

The data was analyzed for distribution using Shapiro-Wilk. All data with normal distribution $(\mathrm{p} \geq 0.05)$ was subsequently analyzed with ANOVA test and
Cite this article: Kusmardi K, Rahyussalim, Wisnubaroto RP, Firzani D. The Combination of Spirulina Extract and Sambiloto Effect Histopathologically on Medial Colon from Plasmodium berghei Anka Infected Mice. Pharmacog J. 2019;11(3):564-9. 
Tukey post hoc test. Data with abnormal distribution $(\mathrm{p}<0.05)$ was analyzed using Kruskal-Wallis test.

\section{RESULTS}

This research involved 24 subjects, therefore the data was analyzed using Shapiro-Wilk. The result revealed that the data of goblet cell count and dysplasia has normal distribution, whereas inflammatory foci and angiogenesis has abnormal distribution. The group was considered normal when the significant value exceeds 0.05 . The 2 groups with normal distribution, goblet cells count and dysplasia, were analyzed using ANOVA test. On the other hand, the abnormal distribution groups, inflammatory foci and angiogenesis, were analysed using Kruskal-Wallis test.

The result from ANOVA test and Kruskal-Wallis test can be seen in table 1. Based on the result, the Kruskal-Wallis test showed a significant difference on the inflammatory foci $(P=0.002)$ and in the number of angiogenesis $(P=0.034)$. In contrary, the result on the number of Goblet cell count $(\mathrm{P}=0.277)$ and dysplasia $(\mathrm{P}=0.562)$ turned out to be insignificant, which was tested using ANOVA.

\section{Goblet Cells Count}

After completing the laboratory work, which included 10 microscopic fields taken randomly from each slide, the results are showed in Figure 1. Pictures above represented the condition of 4 different groups. The average goblet cells were taken by counting the number of goblet cells in one crypt of Lieberkuhn, per one microscopic slide.

From Figure 2, picture A shows that there were approximately 7 goblet cells in one crypt of Lieberkuhn. The number of Goblet cells increased gradually in the second and the third group. The last group Goblet cells count was slightly lower than the third group, but still higher than the first and second group.

Based on the Goblet cells count from Saphiro-Wilk test, the data distribution was normal. The statistical analysis was continued with ANOVA to check whether the data had significant difference or not. The result from ANOVA test proved that the data was insignificant as the P equals to 0.277 . The insignificant result means there was no significant difference between each group, in Goblet cell count category.

Although the graph in Figure 3 shows that there were gaps between the figures of each groups, the gap was not sufficient enough to be considered significant on the statistical analysis. The highest number of Goblet cells count can be found in the third group, where the subject was treated with Sambiloto and Spirulina Powder, $120 \mathrm{mg} / \mathrm{kgBW}$ and $130 \mathrm{mg} / \mathrm{kgBW}$ respectively.

\section{Inflammatory Foci}

Figure 3 represents the microscopic evidence of lowered inflammatory focus number in groups treated with Spirulina extract and powder. In picture $A$, the inflammation focus was concentrated in one broad area, as can be seen in the lower right part of the picture. Group AP+ES and $\mathrm{AP}+\mathrm{PS}$ inflammatory foci number were much less than the first group.

Table 1: Table of statistical data analysis.

\begin{tabular}{cccccc}
\hline & AP & AP+ES & AP+PS & C+DHP & $\begin{array}{c}P \\
\text { value }\end{array}$ \\
\hline Goblet cells & $7.91 \pm 1.10$ & $8.53 \pm 1.03$ & $9.51 \pm 1.87$ & $9.18 \pm 1.73$ & $0.277^{*}$ \\
Inflammatory & 1.20 & 4.50 & 0.45 & 0.85 & $0.002^{* *}$ \\
focus & $(0.8-2.9)$ & $(0.2-0.7)$ & $(0.3-0.7)$ & $(0.5-1.1)$ & \\
Dysplasia & $2.5 \pm 1.11$ & $2.36 \pm 1.21$ & $1.81 \pm 0.70$ & $2.5 \pm 0.61$ & $0.5621^{*}$ \\
Angiogenesis & 4.30 & 1.95 & 2.40 & 3.10 & $0.034^{* *}$ \\
& $(1.6-6.7)$ & $(1.2-2.7)$ & $(1.7-2.7)$ & $(2.2-4.3)$ & \\
\hline
\end{tabular}
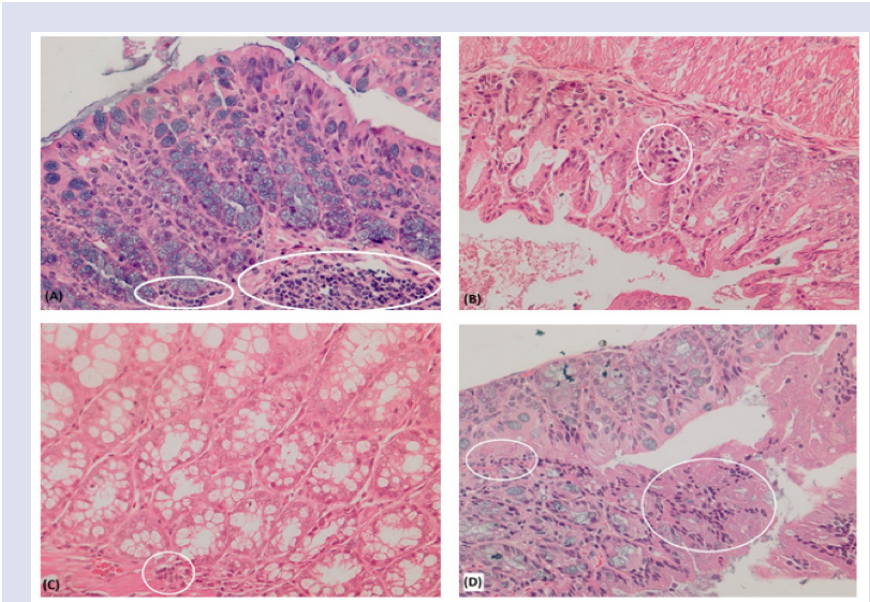

Figure 1: Inflammatory foci appearance on 40x10 magnification. (A) Inflammatory foci in Sambiloto group; (B) Inflammatory foci count in $A P+E S$ group; (C) Inflammatory foci in AP+PS group; (D) Inflammatory foci in control group treated with DHP.
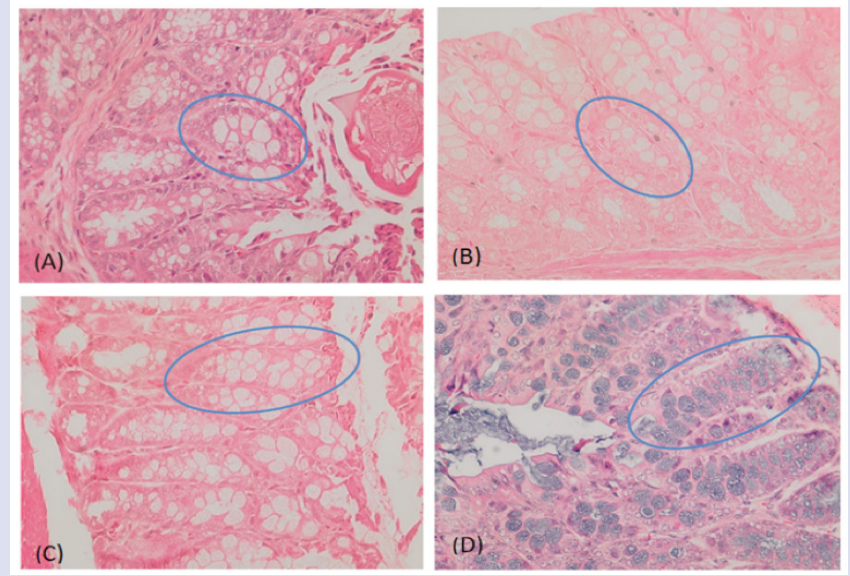

Figure 2: Goblet cell appearance on 40×10 magnification. (A) Goblet cell in Sambiloto group; (B) Goblet cell count in AP+ES group; (C) Goblet cell in AP+PS group; (D) Goblet cell count in control group treated with DHP.

\section{Goblet Cells}

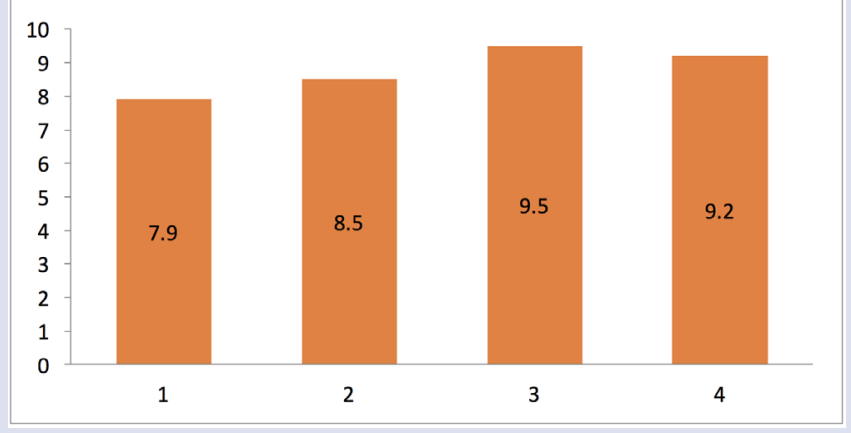

Figure 3: Mean goblet cell graph in 4 groups of infected mice. 
Table 2: Mann-Whitney Test result for Inflammatory foci.

\begin{tabular}{ccc}
\hline \multicolumn{2}{c}{ Groups Compared } & Sig. Inflammatory Foci \\
\hline AP & ES & 0.004 \\
AP & PS & 0.004 \\
AP & Control + DHP & 0.063 \\
ES & PS & 0.871 \\
ES & Control + DHP & 0.035 \\
PS & Control + DHP & 0.035 \\
\hline
\end{tabular}

While the control+DHP group, as presented by picture $\mathrm{D}$, had moderate amount of inflammatory cells that were distributed around the crypts of Lieberkuhn.

Based on laboratory work, the statistical data on the number of inflammatory foci are presented in Table 2.

The data was processed using Kruskal-Wallis test, as the data was not normally distributed. The result showed significant figures that made the groups comparable, with $\mathrm{P}=0.002$. The Kruskal-Wallis test was followed by Mann-Whitney test in order to investigate which group had significant difference. The result revealed that comparation of AP group to $\mathrm{AP}+\mathrm{ES}$ and $\mathrm{AP}+\mathrm{PS}$ group showed significant difference ( $\mathrm{P}$ equaled to 0.004 on both group). Aside from that, the difference of AP+ES and $\mathrm{AP}+\mathrm{PS}$ group to DHP group was proven to be significant, with $\mathrm{P}=0.035$ on each group (as can be seen in table 2).

From the Mann-Whitney result, it can be concluded that the addition of Spirulina, either it is in powder form or extract, can significantly affect the number of inflammatory foci. Even when compared to the Control+DHP group, the 2 groups with additional Spirulina showed a better outcome.

Based on observation from the graph in figure 4, both groups that were treated with Spirulina had a notable difference in comparison with the Sambiloto and Control group. The result on the graph represented the statistical data result accurately.

\section{Dysplasia Rate}

Microscopically, from each of the microscopic field that represented the groups (shown in figure 5), we can found various rate of dysplasia. The rate of dysplasia in group AP and control+DHP were in the same level. Meanwhile, there was a slightly lower number of dysplasia in group $\mathrm{AP}+\mathrm{ES}$. The lowest number of dysplasia rate achieved by third group, which is the AP+PS group.

Following the aforementioned laboratory work steps, the data gained on the dysplasia rate can be seen in the graph in figure 6 . Similar to the Goblet Cell count, the outcome from statistic measures proved that the dysplasia was insignificant using ANOVA test, with $\mathrm{P}=0.562$.

Prior to the ANOVA test, the data was processed using Saphiro-Wilk method, with the result was normally distributed $(P=0.051)$. Since the data was considered normal and proven to be insignificant, therefore the data analysis was not continued.

From the graph in figure 6, the lowest number can be found in the third group, while for the rest of the groups remained at the same level, with a slight decrease in the second group. The $\mathrm{AP}+\mathrm{ES}$ and $\mathrm{AP}+\mathrm{PS}$ group succeeded in lowering the dysplasia rate, even lower than the control group that was treated with DHP. Despite of the good result, the difference was insignificant according to the data analysis.

\section{Angiogenesis}

Based on microscopic examination, the number of angiogenesis in the group A was equally high in most of the slides, as can be seen in the

\section{Inflammatory Foci}

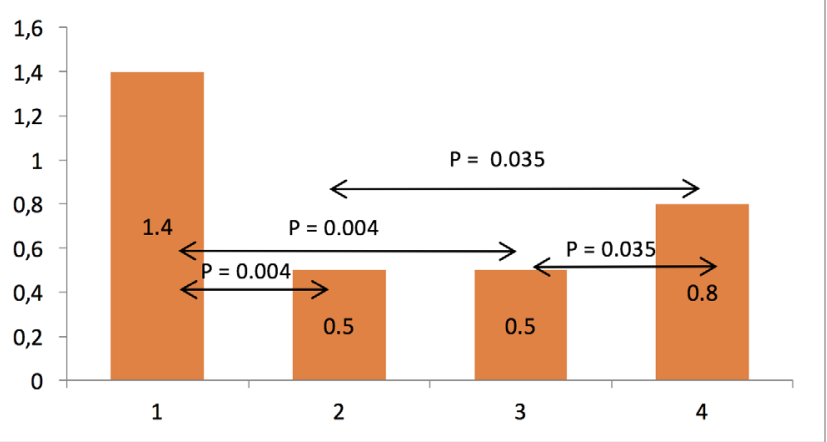

Figure 4: Mean inflammation foci graph in 4 groups of infected mice.
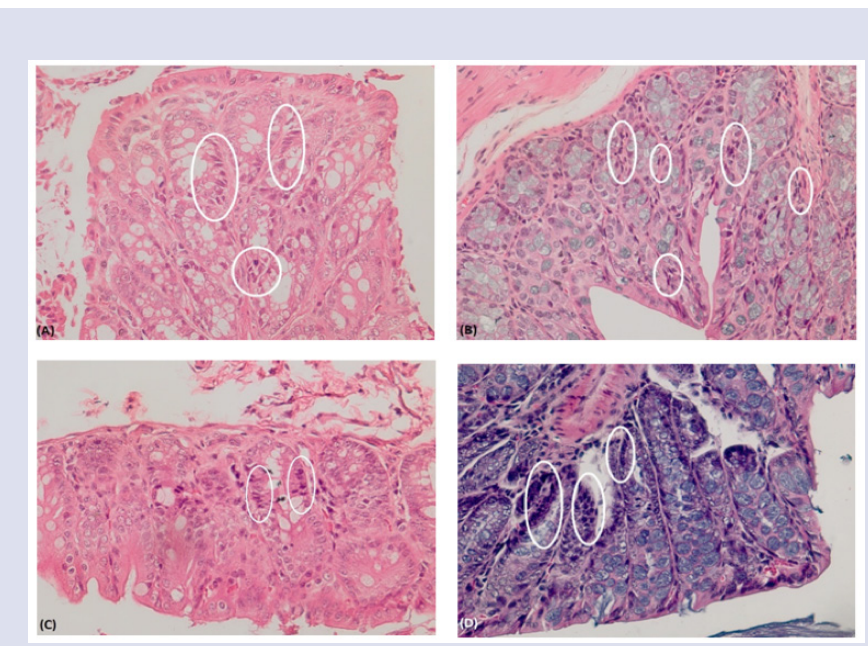

Figure 5: Dysplasia appearance on 40×10 magnification. (A) Dysplasia in Sambiloto group; (B) Dysplasia in AP+ES group; (C) Dysplasia in AP+PS group; (D) Dysplasia in control group treated with DHP.

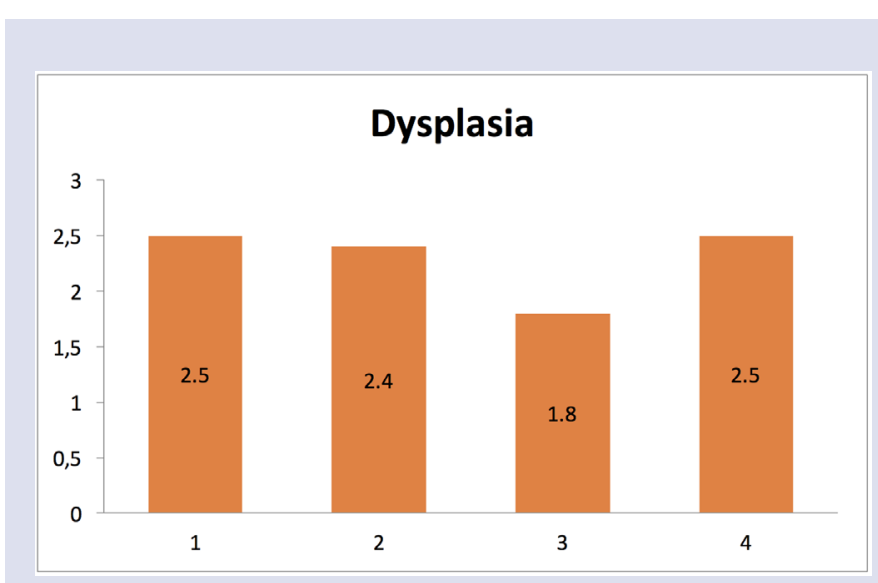

Figure 6: Mean dysplasia graph in 4 groups of infected mice. 

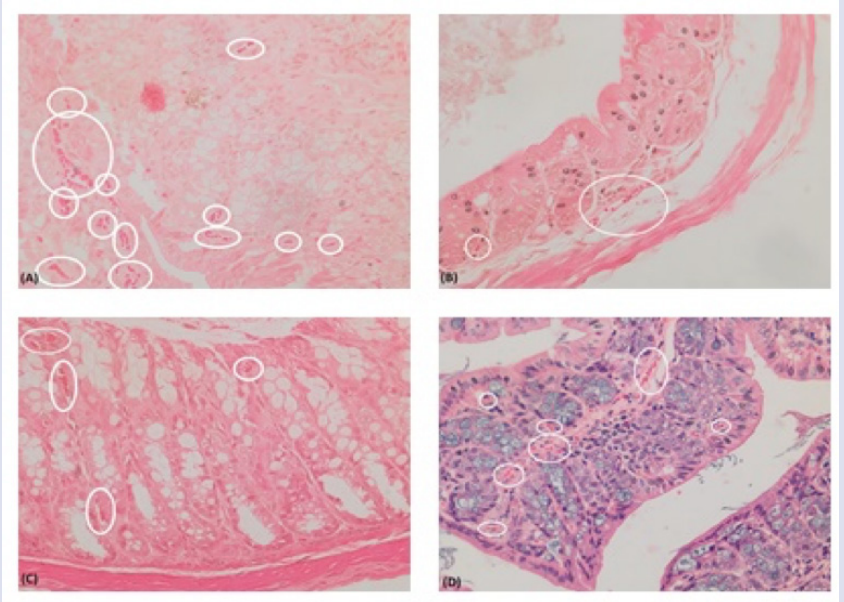

Figure 7: Angiogenesis appearance on 40×10 magnification. (A) Angiogenesis in Sambiloto group; (B) Angiogenesis in AP+ES group; (C) Angiogenesis in AP+PS group; (D) Angiogenesis in control group treated with DHP.

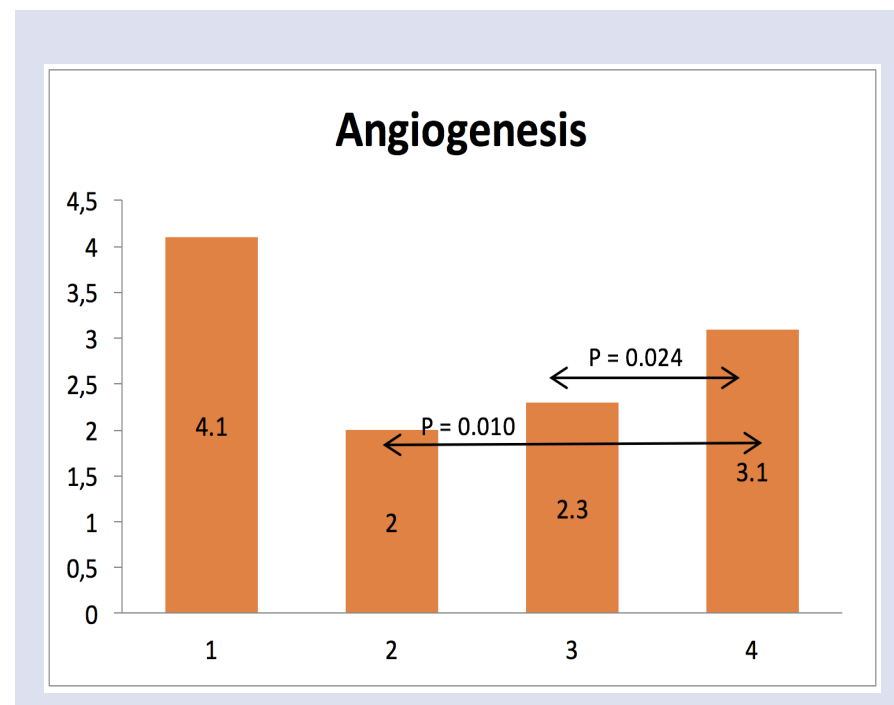

Figure 8: Mean angiogenesis in 4 groups of infected mice.

figure 7, picture A. The number of angiogenesis in group A exceeded the number of angiogenesis from group $\mathrm{D}$, which was control mice treated with DHP. In picture B and C, the number of angiogenesis was very low, especially in group $\mathrm{B}$.

The angiogenesis data was analyzed using Shapiro-Wilk and KruskalWallis test, followed by Mann-Whitney test. Since the data was proven to be abnormally distributed, the data analysis was continued using Kruskal-Wallis test. As the result was significant $(\mathrm{P}=0.034)$, the data was processed using Mann-Whitney test. From the Mann-Whitney test, the result showed that significant difference can be seen from group Control+DHP compared AP+ES $(\mathrm{P}=0.010)$ and Control+DHP compared to $\mathrm{AP}+\mathrm{PS}(\mathrm{P}=0.024)$. As also can be seen from the graph in figure 8, addition of Spirulina to Sambiloto can actually lower the angiogenesis number when compared to the Control group with DHP treatment.

\section{DISCUSSION/ CONCLUSION}

\section{Sambiloto, Spirulina and Goblet Cells Count}

As observed in goblet cells count graph, the data showed the highest number of goblet cells was in mice treated with AP+PS. The goblet cells count in the group treated with Sambiloto and Extract Spirulina also appeared considerably high, although the number was lower than the control group.

In normal condition, the goblet cells works as the front line protection of gastrointestinal tract, by secreting mucin glycoproteins (MUC 2) and bioactive molecules. ${ }^{10-12}$ Commensal intenstinal microbes colonization will formed in the outer most layer of the mucus, whereas the inner part of the mucus layer usually lacks of bacteria. ${ }^{13,14}$ When the number of Goblet cells decreased, there will be lower production of mucin glycoproteins and bioactive molecules. Consequently, the chances of bacterial adhesion in the surface mucus layer will also increase.

During inflammatory condition, the Goblet cells will work to produce more mucins in order to prevent the damage by inflammatory process. This process most likely serves as the background of the rising number of Goblet cells during inflammation period. ${ }^{15}$ This theory was concluded in a study on the goblet cells in lungs during chronic illness. ${ }^{14}$

\section{Sambiloto, Spirulina and Inflammation focus}

The statistical analysis result showed that the addition of Spirulina, in the form of powder and extract, was able to lower the number of inflammatory foci. Addition of extract Spirulina and powder Spirulina gave effect significantly similar to the data presented in the graph where the $\mathrm{AP}+\mathrm{ES}$ group and AP+PS group are in equal level. Despite of the antiinflammatory properties in Sambiloto, the addition of Spirulina actually improved the anti inflammatory activities, as can be seen from the significant result.

Spirulina is known to have beta-carotene and phycocyanine that work as potent antioxidant and anti-inflammatory attributes. The capability of phycocyanin as antiinflammatory substance has been reported in many studies. Phycocyanin antiinflammmatory activities have the ability to inhibits proinflammatory cytokine formation, for example TNFa is able to suppresses cyclooxygenase-2 (COX-2) expression and decrease prostaglandin production. Likewise, beta-carotene also has the ability to reduce inflammatory process in a similar manner like Phycocyanin. ${ }^{16}$

The combination of Sambiloto and Spirulina was proven to be compatible and exhibited the desired outcome as can be seen in the result, despite of the differences in anti-inflammatory substances on each plants. The result was even promising as the number of inflammatory foci in group with powder Spirulina are lower than the control group that treated with DHP.

\section{Sambiloto, Spirulina and Dysplasia Rate}

Based on the result from statistic data analysis, the number of dysplasia rate on 4 groups was proven to be insignificant. Despite of the inconsequential outcome, the graph actually showed gaps on the 2 groups that were given Spirulina, compared to the Sambiloto and control group.

In order to reach dysplasia stage, the celsl need to undergo a long standing process that is associated with inflammation. Constant state of inflammation will expose the cells to be more prone to changes in the structure and function. After the chronic inflammation, the cell will enter hyperplasia stage and then proceed to dysplasia as the alteration of the nucleus morphology occurs. ${ }^{17}$

In this case, the insignificant statistic result most likely because the time and severity factor required to achieve the dysplasia stage in medial colon in this case were insufficient. 


\section{Sambiloto, Spirulina and Angiogenesis}

From statistical analysis result, the number of angiogenesis is lowest was groups with Spirulina extract combination, compared to the other groups. However, there were significant difference in angiogenesis in $\mathrm{AP}+\mathrm{ES}$ and $\mathrm{AP}+\mathrm{PS}$ groups when compared to AP group. Therefore, addition of Spirulina, either in powder or extract, can significantly affect the medial colon of mice by lowering the number of angiogenesis.

Angiogenesis is formation and development of new blood vessels, whether the person is healthy or ill. In some cases, the neovascularization in inflammatory diseases might worsen the progression of inflammatory process. This condition usually occurs in angiogenic inflammatory diseases, for instance in rheumatoid arthritis. In the other hand, it might also helps to restore the blood supply into the damaged tissue or area. ${ }^{18}$

Based on a study on an adjuvant-induced arthritis in rats, it is found that Spirulina has the ability to reduced the serum level of VEGF compared to the control group. This study proved that the polysaccharide extract that was taken from Spirulina had the ability to inhibit the production of VEGF and TNF- $\alpha$, as also mention in other study on alkali burn-induced corneal inflammation and neovascularization. ${ }^{19,20}$

\section{ACKNOWLEDGEMENT}

We are greatly indebted to the residents, doctors, and paramedical staff of Pathological Anatomy Department and Department of Orthopaedic and Traumatology, Cipto Mangunkusumo Hospital, Jakarta, who helped in the preparation of experimental procedure, and The Directorate of Research and Public Services of PITTA Grant

\section{CONFLICT OF INTEREST}

The authors declare that there are no conflicts of interest regarding the publication of this article.

\section{ABBREVIATIONS}

AP: Andrograph paniculata or commonly known as Sambiloto; DHP: dehidroartemisinin dan piperakuin; ES: Extract Spirulina; PS: Powdered Spirulina.

\section{REFERENCES}

1. World Health Organization [database on the Internet]. Malaria. 2016 - [cited 4 March 2016]. Available from: http://www.who.int/mediacentre/factsheets/ fs094/en/

2. CDC [database on the Internet]. Global Health Indonesia Country. 2013 - [cited 25 May 2016]. Available from: http://www.cdc.gov/globalhealth/countries/indonesia/pdf/indonesia_factsheet.pdf

3. Balitbangkes [database on the Internet]. Laporan Riset Kesehatan Dasar (Riskesdas). 2013-[cited 4 March 2016]. Available from: http://www.depkes.go.id/ resources/download/general/Hasil\%20Riskesdas\%202013.pdf

4. Tandon C, Mathur P, Sen M. Andrographis paniculata Nees (Kalmegh): A Review on Its Antibacterial Activities and Phytocompounds. EJMP. 2015;8(1):1-10.

5. Okhuarobo A, Ehizogie Falodun J, Erharuyi O, Imieje V, Falodun A, Langer P. Harnessing the medicinal properties of Andrographis paniculata for diseases and beyond: a review of its phytochemistry and pharmacology. Asian Pacific Journal of Tropical Disease. 2014 Jun;4(3):213-22.

6. Anju D, Jugnu G, Kavita S, Arun N, Sandeep D. A Review On Medicinal Prospectives Of Andrographis Paniculata Nees. 2012;1(1):1-4.

7. MedlinePlus Supplements [database on the Internet]. Blue-green algae. 2016 - [cited 5 March 2016]. Available from:https://www.nlm.nih.gov/medlineplus/ druginfo/natural/923.html

8. Deng R, Chow T. Hypolipidemic, Antioxidant and Antiinflammatory Activities of Microalgae Spirulina. Cardiovascular Therapeutics. 2010;28(4):e33-e45.

9. Khan Z, Bhadouria P, Bisen P. Nutritional and Therapeutic Potential of Spirulina. Current Pharmaceutical Biotechnology. 2005;6(5):373-379.

10. Belay A, Ota Y, Miyakawa K. Current knowledge on potential health benefits of Spirulina. Journal of Applied Phycology. 1993;5(2):235

11. CDC [database on the Internet]. Malaria - About Malaria - Disease. 2016 - [cited 4 March 2016]. Available from: http://www.cdc.gov/malaria/about/disease.htmll

12. World Health Organization. World malaria report. Geneva, Switzerland. 2013.

13. LUMC [database on the Internet]. Lumc.nl.org: Parasitologi of Malaria. 2016 - [cited 5 March 2016]. Available from: https://www.lumc.nl/org/parasitologie/ research/malaria/berghei-model/life-cycle-berghei/

14. Kim YS, Ho SB. Intestinal Goblet Cells and Mucins in Health and Disease : Recent Insights and Progress. 2010;319-30.

15. Saetta M, Turato G, Baraldo S, Zanin A, Braccioni F, Mapp C et al. Goblet Cell Hyperplasia and Epithelial Inflammation in Peripheral Airways of Smokers with Both Symptoms of Chronic Bronchitis and Chronic Airflow Limitation. Am J Respir Crit Care Med. 2000;161(3):1016-1021.

16. Deng R, Chow T. Hypolipidemic, Antioxidant and Antiinflammatory Activities of Microalgae Spirulina. Cardiovascular Therapeutics. 2010;28(4):e33-e45.

17. Falate. Colitis, Dysplasia and Cancer. Nutrition Reviews. 2009;47(10):314-317.

18. Szekanecz Z Koch A. Mechanisms of Disease: angiogenesis in inflammatory diseases. Nature Clinical Practice Rheumatology. 2007;3(11):635-643.

19. Ali E, Barakat B, Hassan R. Antioxidant and Angiostatic Effect of Spirulina platensis Suspension in Complete Freund's Adjuvant-Induced Arthritis in Rats. PLOS ONE. 2015;10(4):e0121523

20. Yang LL, Zhou QJ, Wang Y, Gao Y, Wang YQ. Comparison of the therapeutic effects of extracts from Spirulina platensis and amnion membrane on inflammation-associated corneal neovascularization. Int J Ophthalmol. 2012;5: 32-37.

\section{GRAPHICAL ABSTRACT}

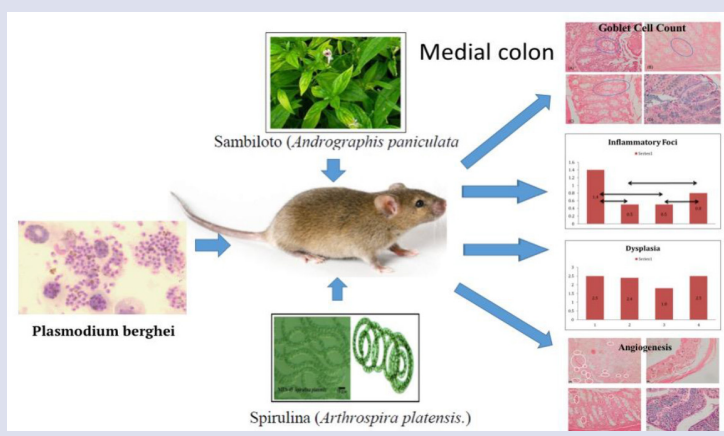

\section{SUMMARY}

- This research proved that combination of Sambiloto and Spirulina has beneficial effect in treatment of Plasmodium berghei Anka infection. Administration of Sambiloto alone did not show significant result when compared with control group. Addition of Spirulina, in extract or powder form, can actually reduce inflammatory activity by lowering angiogenesis and inflammatory foci. Anti-inflammatory properties of Sambiloto is due to its bioactive component such as andrographolide and phycocyanin that inhibit pro inflammatory mediators. Goblet cells count increase as inflammation occurs, as it has functions as protective part in mucous layer. Inflammatory cytokines also have angiogenic properties, as increase of inflammation process will recruit inflammatory mediators and promote angiogenesis . 


\section{ABOUT AUTHORS}

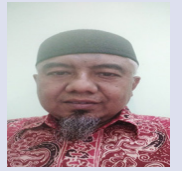

Kusmardi Kusmardi: Senior Lecturer and Researcher at Anatomic Pathology, Faculty of Medicine, Universitas Indonesia. The major research focus on colorectal and breast cancer, include the potential inhibition of some Indonesian natural medicine on the both carcinogenesis, the indentification of normal tissue vs cancer development using some molecular marker and computational model. He wrote the mouse model for breast cancer book, the mouse model for colorectal adjuvant chemopreventive book, and Lunasin: a soybean polypeptide as chemopreventive adjuvant for colon cancer. He was The Best Young Researcher, Indonesian Council of Sciences (LIPI) on 1996 and 1998; The Best Researcher of Indonesian Oncology Association, 2000; The Potential Researcher at Faculty of Medicine Universitas Indonesia, 2013. From 2014 up till now, he was Editor-in-Chief of The Indonesian Journal of Pathology and The Journal of Pratista Pathology Universitas Indonesia. From 2016 up till now, he was The chairman of Academic Quality Assurance Team of PhD Program, Faculty of Medicine Universitas Indonesia. From 2012 up till now he was the Indonesian Assessor of Medical School Quality Assurance.

Cite this article: Kusmardi K, Rahyussalim, Wisnubaroto RP, Firzani D. The Combination of Spirulina Extract and Sambiloto Effect Histopathologically on Medial Colon from Plasmodium berghei Anka Infected Mice. Pharmacog J. 2019;11(3):564-9. 